\title{
Study on Genotypic Differences in Photosynthetic Nitrogen Use Efficiency, Nitrogen Use Efficiency, Yield and Yield Related Traits in Different Rice Genotypes under Different Nitrogen Levels
}

\author{
V. Aparna ${ }^{1 *}$, S. Narender Reddy ${ }^{1}$ and D. Subrahmanyam ${ }^{2}$ \\ ${ }^{1}$ Department of Crop Physiology, Professor Jayashankar Telangana State Agricultural \\ University, Hyderabad, Telangana, 500030, India \\ ${ }^{2}$ Department of Plant Physiology, IIRR, Rajendranagar, Telangana, 500030, India \\ *Corresponding author
}

\section{A B S T R A C T}

Keywords

Nutrient,

Genotypes, Rice,

Nitrogen use

efficiency,

Recommended dose

of nitrogen

Article Info

Accepted:

17 March 2019

Available Online:

10 April 2019

Nitrogen is the major nutrient element required for the plant growth and development. In rice, development of varieties with improved nitrogen use efficiency will reduce the nitrogen fertilizer application. This study was investigating the genotypic differences in photosynthetic nitrogen use efficiency, nitrogen use efficiency, yield and yield related traits of 12 different rice genotypes under two different nitrogen levels viz., T1 and T2. Different physiological and agronomical characters were measured in selected 12 genotypes, growing in field. The photosynthetic rate was recorded higher $\left(23.3 \mu \mathrm{mol} \mathrm{CO}_{2}\right.$ $\mathrm{m}^{-2} \mathrm{~s}^{-1}$ ) with rice genotype Sampada. Efficiency parameters including Photosynthetic Nitrogen Use Efficiency and Harvest Index were studied in order to determine NUE. Chlorophyll content was recorded maximum in vegetative stage under $100 \%$ RDN and in reproductive stage under T1 and T2 in NUE genotype of Vardhan and minimum in low NUE genotype Sampada x Jaya/3 under T1 and T2 treatments. Total Dry Matter, grain yield and leaf nitrogen content were higher in high NUE genotype Vardhan. High chlorophyll content in case of Vardhan under low nitrogen content support their higher grain yield and total dry matter content. The Nitrogen Use Efficiency (7.11) and photosynthetic nitrogen use efficiency (12.50) were lower when treated with $100 \%$ of recommended Nitrogen. The maximum average grain yield of $824 \mathrm{~g} \mathrm{~m}^{-2}$ was registered in Vardhan genotype.

\section{Introduction}

Rice (Oryza sativa L.) is one of the most important food crop grown and is consumed by one-third of the world's population. In order to support the increasing population the yields has to be increased. Nitrogen is an important primary constituent of the nucleotides, amino acids, proteins, chlorophyll and several plant hormones. It is one of the most important nutrients in improving crop yields. Nitrogen is responsible for improving panicle number and grain weight and responsible for reducing spikelet sterility (Fageria, 2009). Though, application of nitrogen fertilizers increases crop yields, increased use of $\mathrm{N}$ fertilizers 
effects global $\mathrm{N}$ cycle, depletion of ozone layer and also causes nitrate leaching problems in soil (Hakeem et al., 2012). Out of the total amount of applied nitrogen, only 30 $40 \%$ of the applied $\mathrm{N}$ reaches the plant and the remaining is lost to the environment (Raun and Johnson, 1999). Hence, using Nefficient genotypes is an important strategy in reducing cost of production as well as environmental pollution.

Nitrogen use efficiency has been defined as grain yield per unit of $\mathrm{N}$ available in the soil (Good et al., 2004). At higher $\mathrm{N}$ rates, the decrease in NUE indicates that rice plants could not absorb or utilize $\mathrm{N}$ at higher rates or that $\mathrm{N}$ loss exceeded the rate of plant uptake. Nitrogen use efficient genotypes can be defined as plants which can absorb and accumulate higher $\mathrm{N}$ content and grow well and yield better under low $\mathrm{N}$ conditions (Mi et al., 2007). NUE is relatively low in rice as major part of $\mathrm{N}$ applied to rice is released as gaseous $\mathrm{N}$, effecting environment and reducing economic efficiency of applied $\mathrm{N}$ (Hakeem et al., 2012). In order to protect environment it is very important to identify or develop high NUE rice genotypes for its production under low cost management practices. Rice genotypes differ in their NUE and also in their response to added $\mathrm{N}$ which can be explored and further utilized in the development of efficient genotypes for $\mathrm{N}$ limiting environments.

Photosynthetic $\mathrm{N}$ use efficiency is the ratio between Net photosynthesis rate and Leaf $\mathrm{N}$ content. NUE biomass is largely affected by $\mathrm{N}$ concentrations, $\mathrm{N}$ partitioning between stems and leaves, $\mathrm{N}$ efficiency in converting $\mathrm{CO} 2$ to carbohydrate through photosynthesis, vertical $\mathrm{N}$ distribution in a canopy, RUBISCO activity and leaf senescence.

The identification of genotypes with high Nitrogen use would minimize the use of expensive chemical fertilizers and encourage sustainable agriculture. Genotypes differ in their ability to absorb and utilize nutrients and genetic variation in nitrogen use efficiency (NUE) in rice it was reported by many workers. Hence, to understand the genetic variation rice genotypes for their responsiveness to nitrogen, the present study has been designed to the following objective to determine the physiological basis of the nitrogen efficiency of rice genotypes under two varied nitrogen regimes.

\section{Materials and Methods}

\section{Site description}

The field experiment was conducted at Indian Institute of Rice Research, Rajendranagar, Hyderabad during Kharif 2016. It comes under Southern Telangana agro-climatic zone of Telangana state. The weather data on rainfall, number of rainy days, mean maximum and minimum temperatures, relative humidity, evaporation and sunshine hours recorded from June to November 2016 at the Meteorological Observatory of Agricultural Research Institute, Rajendranagar, Hyderabad. During cropping period in 2016, the average maximum and minimum temperature were 28.7 and 20.35 respectively. The total rainfall received was $839 \mathrm{~mm}$ and the average maximum and minimum relative humidity was 88.3 and $57.83 \%$. the average bright sunshine hours was $5.2 \mathrm{~h}$ with a average evaporation rate of $3.95 \mathrm{~mm}$. Different physical and chemical analysis of the soil sample was done by adopting standard procedures.

\section{Experimental design and crop management}

A field experiment was conducted with 2 nitrogen levels of T1- 50\% Recommended Dose of Nitrogen and T2- 100\% Dose of Nitrogen and 12 rice genotypes with 3 replications. Recommended P: K (60:40) 
along with two treatments of nitrogen was applied. Recommended dose of fertilizer was applied in the form of urea, single super phosphate and muriate of potash. Nitrogen was applied in three splits at basal stage, maximum vegetative stage and panicle initiation stage whereas $\mathrm{P}_{2} \mathrm{O}_{5}$ and $\mathrm{K}_{2} \mathrm{O}$ was applied @ 60:40 kg/ha as basal. One month old seedlings were transplanted in the main field. A spacing of $20 \times 10 \mathrm{~cm}$ was adopted uniformly. A thin layer of $2-3 \mathrm{~cm}$ water was maintained constantly till the establishment of seedlings. Thereafter about $5 \mathrm{~cm}$ of water was maintained up to dough stage of the crop. Irrigation was withheld at the physiological maturity of the crop.

\section{Sampling, observation and calculation}

Five plants per plot were sampled at vegetative stage, flowering and harvest stage for recording the observations. The observations were made on different agronomic and physiological characters in each treatment.

\section{Chlorophyll content}

The quantitative determination of leaf chlorophyll content was done using a spectrophotometer. $25 \mathrm{mg}$ of the fresh leaf tissue of each sample was cut into small pieces and placed into $10 \mathrm{ml}$ tubes containing $10 \mathrm{ml}$ of $80 \%$ acetone and kept in dark for $1-2$ days to ensure complete extraction of leaf chlorophyll pigment. The absorbance of the chlorophyll solution was measured by using a UV-VIS double beam spectrophotometer (Spectrascan 2600, Chemito). Chl a, Chl b and Carotenoids were measured at 663.2, 646.8 and $470 \mathrm{~nm}$ respectively. The chlorophyll content expressed in $\mathrm{mg} / \mathrm{g}$ fresh weight was measured at maximum vegetative stage. The content of $\mathrm{Chl} \mathrm{a}, \mathrm{Chl} \mathrm{b}$, Total chlorophyll and Carotenoids were calculated as per the formulae given by Lichtenthaler and Wellburn (1983).

Chl a $(\mu \mathrm{g} / \mathrm{ml})=12.25 \mathrm{~A}_{663.2}-2.79 \mathrm{~A}_{646.8}$

Chl b $(\mu \mathrm{g} / \mathrm{ml})=21.5 \mathrm{~A}_{646.8}-5.1 \mathrm{~A}_{663.2}$

Total chlorophyll $(\mu \mathrm{g} / \mathrm{ml})=\mathrm{Chl} \mathrm{a}+\mathrm{Chl} \mathrm{b}$

Carotenoids $=\left(1000 \mathrm{~A}_{470}-1.82 \mathrm{Chl} \mathrm{a}-85.02\right.$

Chl b) / 198

$\mathrm{Chl} \mathrm{a/b}$ and Chlorophyll/Carotenoid.

\section{Gas exchange parameters}

Photosynthetic characteristics such as Photosynthetic rate $\left(\mathrm{P}_{\mathrm{N}}\right)$, Stomatal conductance $\left(\mathrm{g}_{\mathrm{s}}\right)$, Transpiration rate $(\mathrm{E})$ and Internal $\mathrm{CO}_{2}$ concentration $\left(\mathrm{C}_{\mathrm{i}}\right)$ were recorded at maximum vegetative stage by using Li-Cor 400 (IRGA) portable photosynthesis measurement system attached to leaf chamber flurometer (LCF model 6400-1, LICOR, USA) which is used as artificial light source. During measurements the Photosynthetic Active Radiation (PAR) was kept at 1200 $\mu \mathrm{mol} \mathrm{m} \mathrm{m}^{-2} \mathrm{~s}^{-1}$ and $\mathrm{CO}_{2}$ concentration was kept at $387 \pm 6 \mathrm{ppm}$. These measurements were made between 10.00 am to 12.00 noon at all sampling dates.

\section{$\mathbf{N}$ content}

Nitrogen content in leaf, stem and root was estimated following to Kjeldahl method using block digestion and steam distillation. Nitrogen content was expressed as per cent by using the following formula:

(Titrate value - Blank) x N x 14007 x 100

$\mathrm{N}(\%)=$

Weight of sample (mg)

\section{Yield and yield components}

The parameters like number of productive tillers per plant, number of grains per panicle and thousand grain weights and grain yield per plant were recorded at maturity for assessing the relationship between yield and 
its components. The yield samples were dried to a constant weight and threshed manually to determine the grain yield which was then expressed in $\mathrm{g} \mathrm{m}^{-2}$.

\section{Partial Factor Productivity of Nitrogen (PFPN)}

PFPN (in kilograms of grain per kilogram of $\mathrm{N}$ applied) were calculated as following equation: $\mathrm{PFPN}=$ Yield/ $\mathrm{N}_{\text {input }}$ (Zhang et al., 2018).

\section{Photosynthetic nitrogen use efficiency}

PNUE, determined by photosynthetic rate per unit leaf organic $\mathrm{N}$ content (Li, Y., et al., 2011).

\section{Harvet index}

Harvest index was calculated by using the formula economic yield/ biological yield $\mathrm{x}$ 100.

\section{Data processing and statistical analysis}

The data generated on various parameters during the course of investigation were statistically analysed by applying the technique of analysis of variance (Gomez, 1984).

\section{Results and Discussion}

\section{Leaf pigment content}

Non-significant differences was observed between genotypes for chl a and chl b contents in both $\mathrm{T} 1$ and $\mathrm{T} 2$ treatments (Table. 4.1). These pigment levels were more in high NUE genotype Vardhan. The total chlorophyll content increased with increased $\mathrm{N}$ content at reproductive stage. Similar results were observed by Pramanik and Bera (2013). Total chlorophyll content and chlorophyll/carotenoid ratio showed nonsignificant difference among genotypes in both T1 and T2 treatments. Significant differences was observed among genotypes for carotenoid content and for chl $\mathrm{a} / \mathrm{b}$ ratio (Table 4.2).

\section{Characteristics of photosynthetic gas exchange}

Both high NUE and low NUE genotypes exhibited significantly higher values of $\mathrm{P}_{\mathrm{N}}, \mathrm{g}_{\mathrm{s}}$ and $\mathrm{T}$ in $\mathrm{T} 2$ than those of $\mathrm{T} 1$ (Table 4.3). Among nitrogen levels, T2 exhibited significantly higher mean photosynthetic rate $\left(23.3 \mu \mathrm{mol} \mathrm{CO} \mathrm{Cm}^{-2} \mathrm{~s}^{-1}\right)$ and the lowest mean photosynthetic rate was observed in T1 (19.6 $\mu \mathrm{mol} \mathrm{CO}_{2} \mathrm{~m}^{-2} \mathrm{~s}^{-1}$ ). Sun et al., (2012) observed increased photosynthetic rate with increased nitrogen. This may be attributed to higher chloroplast $\mathrm{CO}_{2}$ content, chloroplast size, Rubisco activity and carboxylation capacity (Li et al., 2009). The $\mathrm{C}_{\mathrm{i}}$ in rice plants fed high $\mathrm{N}$ was lower than in those fed low $\mathrm{N}$. The same result was observed by Li et al., 2012. Significant differences for $\mathrm{P}_{\mathrm{N}}, \mathrm{g}_{\mathrm{s}}, \mathrm{T}$ and $\mathrm{C}_{\mathrm{i}}$ were observed between genotypes in $\mathrm{T} 1$ and T2 treatments. In this study low NUE genotype Sampada exhibited highest photosynthetic rates in both $\mathrm{T} 1$ and $\mathrm{T} 2$ (22 and $24.60 \mu \mathrm{mol} \mathrm{m}^{-2} \mathrm{~s}^{-1}$ ) and Vardhan $\mathrm{x}$ BPT5204/10 exhibited highest stomatal conductance $\left(0.9 \mu \mathrm{mol} \quad \mathrm{H}_{2} \mathrm{O} \quad \mathrm{m}^{-2} \quad \mathrm{~s}^{-1}\right)$, transpiration $\left(\begin{array}{llll}9.7 & \mathrm{H}_{2} \mathrm{O} & \mathrm{m}^{-2} & \mathrm{~s}^{-1}\end{array}\right)$ and intercellular $\mathrm{CO}_{2}$ concentration $(313 \mu \mathrm{mol}$ $\mathrm{mol}^{-1}$ ) among all twelve genotypes tested.

\section{Yield and yield components}

Nitrogen significantly improved yield of rice by improving yield components like tiller number, number of filled grains per panicle and reduced grain sterility. The increment of grain yield in this study at higher nitrogen levels might be due to efficient production and translocation of the dry matter from 
source to sink as a result of absorption of nitrogen and other elements. The highest number productive tillers per plant (23) were recorded when the crop fertilized with $100 \%$ of recommended nitrogen whereas lowest number of tillers per plant (8) was observed from crop fertilized with $50 \%$ RDN.

Similar were reported by Ahmed et al., (2005) who reported higher number of productive tillers with higher level of added nitrogen. Rajput et al., (1988) found that more number of tillers $\mathrm{m}^{2}$ might be due to the more availability of nitrogen that played a vital role in cell division.

Panicle traits such as panicle number ${ }^{-2}$, panicle length, panicle dry weight, number of filled grains per panicle and spikelet sterility have been important for rice breeders because they are crucial determinants of grain yield. Panicle number recorded significant difference with nitrogen levels. Highest number of panicles (580) was recorded at $100 \%$ RDN and lowest (313) was recorded at $50 \%$ RDN. During the beginning of panicle development there exists competition for assimilates between developing panicles and young tillers resulting in suppression of growth of many young tillers therefore they may senesce without producing panicle.

Significant difference was observed between $\mathrm{N}$ levels and genotypes for panicle length, number of filled grains per panicle and spikelet sterility. Application of different $\mathrm{N}$ levels had no significant effect on 1000-grain weight, but it was found that application on different genotypes affected on 1000-grain weight significantly. The highest 1000 - grain weight $(28.5 \mathrm{~g})$ was obtained from the plots of Sampada x Jaya/3, while minimum 1000grain weight $(13.50 \mathrm{~g})$ was produced by Vardhan x BPT 5204/10. Tayefe et al., (2014) also showed the same result. High NUE genotype showed more grain yield than that of low NUE genotype in both the treatments and the difference was more in $\mathrm{T} 2$ than that of T1.

There were no significant differences in grain yield with the T1 and T2 treatments, whereas the yields with the T2 treatments were higher than those of the T1 treatment. Numerous studies have shown that the response of grain yield to $\mathrm{N}$ input fits a linear-plateau or convex quadratic model (Zhang et al., 2015). Thus, a small decrease in the theoretical maximum achievable yield caused by reduction of $\mathrm{N}$ application rate will not severely reduce the grain yield in practice (Zhang et al., 2018).

\section{Partial factor productivity of nitrogen}

The results showed that the NUE was higher at $50 \% \mathrm{RDN}$ when compared to $100 \% \mathrm{RDN}$. There was a significant difference in the PFPN among the treatments (Table 4.4). It is due to less utilization when compared to absorption at higher $\mathrm{N}$ concentration. Decreasing NUE at higher $\mathrm{N}$ rates indicates that rice plants could not absorb or utilize $\mathrm{N}$ at higher rates or that $\mathrm{N}$ loss exceeded the rate of plant uptake (Devika et al., 2018).

\section{Effects of $\mathbf{N}$ levels on $\mathbf{N}$ content}

The $\mathrm{N}$ content of roots, stems, and leaves increased with increasing $\mathrm{N}$ supply (Table 4.5). Within the plant nitrogen content was highest in leaf. Large part of the $\mathrm{N}$ in the rice plant is present in leaves throughout the life of the plants. This supports the chloroplasts which in turn drives the dry matter production of the plant through photosynthesis. Leaf $\mathrm{N}$ content is closely correlated with single leaf photosynthetic rate in rice plants grown in pots (Yoshida and Coronel, 1976). Canopy photosynthetic rate is affected by leaf area which in turn affected by leaf $\mathrm{N}$. The mean value of leaf $\mathrm{N}$ was highest $(2.07 \%)$ in Vardhan genotype and the lowest value 
(1.49\%) was found in Rasi genotype. The mean value of stem $\mathrm{N}$ was highest $(0.85 \%)$ in Rasi genotype and the lowest value $(0.44 \%)$ was found in Vardhan genotype. The mean value of root $\mathrm{N}$ was highest $(0.97 \%)$ in Rasi genotype and the lowest value $(0.70 \%)$ was found in Sampada x Jaya/3 genotype.

Effects of $\mathbf{N}$ concentration on PNUE of newly expanded leaves of rice plants

PNUE is higher in genotypes with low leaf $\mathrm{N}$ content when compared with genotypes with high leaf $\mathrm{N}$ content (Table 4.6). Although leaf $\mathrm{N}$ content increases with high $\mathrm{N}$ supply, photosynthetic nitrogen use efficiency is lower in high $\mathrm{N}$-content leaves of certain species (Sage and Pearcy, 1987). The proportion of total leaf $\mathrm{N}$ in the thylakoids remains constant with increasing leaf $\mathrm{N}$ content, whereas leaf soluble $\mathrm{N}$ increases (Makino and others 1997). Mae (1997) concluded that the maximum rate of $\mathrm{CO}_{2}$ assimilation per unit leaf area is almost proportional to the leaf nitrogen which might be due to large part of leaf nitrogen is present in chloroplasts.

\section{Harvest index}

Nitrogen fertilization had no significant effect on harvest index (HI). The HI was marginally higher under T1 when compared to T2. Vardhan has highest and MTU 1010 has lowest HI.

Table.1 The influence of nitrogen on leaf chlorophyll a, chlorophyll b and total chlorophyll in different rice genotypes

\begin{tabular}{|c|c|c|c|c|c|c|c|c|c|}
\hline \multirow[t]{2}{*}{ Genotypes } & \multicolumn{3}{|c|}{ Chlorophyll a } & \multicolumn{3}{|c|}{ Chlorophyll b } & \multicolumn{3}{|c|}{ Total Chlorophyll } \\
\hline & T1 & $\mathbf{T} 2$ & Mean & T1 & $\mathbf{T} 2$ & Mean & T1 & $\mathbf{T} 2$ & Mean \\
\hline $\begin{array}{l}\text { Varadhan x BPT } \\
5204 / 6\end{array}$ & 6.88 & 5.58 & 6.23 & 1.64 & 1.26 & 1.45 & 8.51 & 6.84 & 7.68 \\
\hline $\begin{array}{l}\text { Varadhan x BPT } \\
5204 / 10\end{array}$ & 5.53 & 5.77 & 5.65 & 1.3 & 1.36 & 1.33 & 6.83 & 7.13 & 6.98 \\
\hline Sampada x Jaya/2 & 5.66 & 5.82 & 5.74 & 1.3 & 1.32 & 1.31 & 6.97 & 7.14 & 7.05 \\
\hline Sampada x Jaya/3 & 5.31 & 4.62 & 4.97 & 1.29 & 1.09 & 1.19 & 6.6 & 5.72 & 6.16 \\
\hline $\begin{array}{l}\text { Varadhan x MTU } \\
1010 / 2\end{array}$ & 5.84 & 5.35 & 5.59 & 1.4 & 1.24 & 1.32 & 7.05 & 6.59 & 6.82 \\
\hline Rasi x Jaya/2 & 5.02 & 5.06 & 5.04 & 1.14 & 1.15 & 1.15 & 6.16 & 6.21 & 6.19 \\
\hline Varadhan & 4.93 & 6.67 & 5.8 & 1.11 & 4.37 & 2.74 & 6.04 & 11.04 & 8.54 \\
\hline BPT-5204 & 5.95 & 3.91 & 4.93 & 1.48 & 0.98 & 1.23 & 7.42 & 4.76 & 6.09 \\
\hline Sampada & 5.47 & 4.92 & 5.19 & 1.31 & 1.24 & 1.27 & 6.77 & 6.16 & 6.47 \\
\hline Jaya & 4.58 & 4.84 & 4.71 & 1.14 & 1.19 & 1.16 & 5.72 & 6.02 & 5.87 \\
\hline MTU-1010 & 5 & 5.21 & 5.1 & 1.22 & 1.22 & 1.22 & 6.22 & 6.43 & 6.32 \\
\hline Rasi & 4.93 & 6.15 & 5.54 & 1.21 & 1.44 & 1.32 & 6.14 & 7.59 & 6.86 \\
\hline Mean & 5.42 & 5.32 & 5.37 & 1.3 & 1.49 & 1.39 & 6.7 & 6.8 & 6.75 \\
\hline Treatments (T) & \multicolumn{3}{|c|}{ NS } & \multicolumn{3}{|c|}{ NS } & \multicolumn{3}{|c|}{ NS } \\
\hline Genotypes (G) & \multicolumn{3}{|c|}{ NS } & \multicolumn{3}{|c|}{ NS } & \multicolumn{3}{|c|}{ NS } \\
\hline T xG & \multicolumn{3}{|c|}{1.84} & \multicolumn{3}{|c|}{1.95} & \multicolumn{3}{|c|}{3.54} \\
\hline
\end{tabular}


Table.2 The influence of nitrogen on leaf chlorophyll a/b, carotenoids and chlorophyll/carotenoids in different rice genotypes

\begin{tabular}{|c|c|c|c|c|c|c|c|c|c|}
\hline \multirow[t]{2}{*}{ Genotypes } & \multicolumn{3}{|c|}{ Chlorophyll a/Chlorophyll b } & \multicolumn{3}{|c|}{ Carotenoids } & \multicolumn{3}{|c|}{ Chlorophyll /Carotenoids } \\
\hline & T1 & T2 & Mean & T1 & T2 & Mean & T1 & $\mathbf{T} 2$ & Mean \\
\hline $\begin{array}{l}\text { Varadhan x BPT } \\
5204 / 6\end{array}$ & 4.03 & 4.45 & 4.24 & 2.98 & 2.57 & 2.78 & 2.2 & 2.3 & 2.25 \\
\hline $\begin{array}{l}\text { Varadhan x BPT } \\
\text { 5204/10 }\end{array}$ & 4.26 & 4.24 & 4.25 & 2.49 & 2.96 & 2.72 & 2.26 & 2.32 & 2.29 \\
\hline Sampada x Jaya/2 & 4.34 & 4.41 & 4.38 & 3.18 & 3.11 & 3.14 & 2.21 & 2.27 & 2.24 \\
\hline Sampada $\times$ Jaya/3 & 4.11 & 4.24 & 4.18 & 2.87 & 2.16 & 2.52 & 2.31 & 2.34 & 2.33 \\
\hline $\begin{array}{l}\text { Varadhan x MTU } \\
1010 / 2\end{array}$ & 4.16 & 4.33 & 4.24 & 3.05 & 2.88 & 2.97 & 2.19 & 2.28 & 2.24 \\
\hline Rasi x Jaya/2 & 4.38 & 4.43 & 4.41 & 2.73 & 3.09 & 2.91 & 2.32 & 2.26 & 2.29 \\
\hline Varadhan & 4.4 & 3.29 & 3.85 & 2.97 & 1.91 & 2.44 & 2.34 & 4.97 & 3.66 \\
\hline BPT-5204 & 4.03 & 3.98 & 4 & 3.15 & 2.52 & 2.84 & 2.43 & 2.31 & 2.37 \\
\hline Sampada & 4.18 & 3.94 & 4.06 & 2.99 & 3.38 & 3.18 & 2.34 & 2.34 & 2.34 \\
\hline Jaya & 4.03 & 4.08 & 4.05 & 2.29 & 2.96 & 2.62 & 2.39 & 2.37 & 2.38 \\
\hline MTU-1010 & 4.1 & 4.27 & 4.18 & 2.78 & 2.22 & 2.5 & 2.24 & 2.37 & 2.3 \\
\hline Rasi & 4.08 & 4.27 & 4.18 & 2.23 & 3.35 & 2.79 & 2.39 & 2.39 & 2.39 \\
\hline Mean & 4.17 & 4.16 & 4.17 & 2.81 & 2.76 & 2.78 & 2.3 & 2.54 & 2.42 \\
\hline Treatments (T) & \multicolumn{3}{|c|}{ NS } & \multicolumn{3}{|c|}{ NS } & \multicolumn{3}{|c|}{ NS } \\
\hline Genotypes (G) & \multicolumn{3}{|c|}{0.52} & \multicolumn{3}{|c|}{0.52} & \multicolumn{3}{|c|}{ NS } \\
\hline T xG & \multicolumn{3}{|c|}{0.74} & \multicolumn{3}{|c|}{ NS } & \multicolumn{3}{|c|}{ NS } \\
\hline
\end{tabular}

Table.3 The influence of nitrogen on leaf photosynthetic traits in different rice genotypes

\begin{tabular}{|c|c|c|c|c|c|c|c|c|c|c|c|c|}
\hline \multirow[t]{2}{*}{ Genotypes } & \multicolumn{3}{|c|}{$\begin{array}{l}\text { Photosynthetic rate } \\
\left(\mathbf{P}_{\mathrm{N}}\right) \mu \operatorname{mol}\left(\mathrm{CO}_{2}\right) \mathrm{m}^{-2} \mathrm{~S}^{-1}\end{array}$} & \multicolumn{3}{|c|}{$\begin{array}{l}\text { Stomatal Conductance } \\
\mu \mathrm{mol}\left(\mathrm{H}_{2} \mathrm{O}\right) \mathrm{m}^{-2} \mathrm{~S}^{-1}\end{array}$} & \multicolumn{3}{|c|}{$\begin{array}{l}\text { Transpiration mmol } \\
\left(\mathrm{H}_{2} \mathrm{O}\right) \mathrm{m}^{-2} \mathrm{~S}^{-1}\end{array}$} & \multicolumn{3}{|c|}{$\begin{array}{l}\text { Intercellular } \mathrm{CO}_{2} \\
\text { concentration } \mu \mathrm{mol} \mathrm{mol}\end{array}$} \\
\hline & T1 & T2 & $\begin{array}{l}\text { Mea } \\
\text { n }\end{array}$ & T1 & $\mathbf{T} 2$ & Mean & T1 & T2 & Mean & T1 & $\mathbf{T 2}$ & Mean \\
\hline $\begin{array}{l}\text { Varadhan x BPT } \\
5204 / 6\end{array}$ & 20.1 & 24.9 & 22.5 & 0.6 & 0.7 & 0.6 & 8.6 & 9.1 & 8.9 & 301 & 292 & 297 \\
\hline $\begin{array}{l}\text { Varadhan x BPT } \\
5204 / 10\end{array}$ & 18.2 & 22.9 & 20.6 & 0.5 & 1.3 & 0.9 & 8.4 & 10.9 & 9.7 & 302 & 325 & 313 \\
\hline Sampada x Jaya/2 & 21.7 & 24.2 & 22.9 & 0.6 & 0.7 & 0.6 & 8.9 & 9.8 & 9.4 & 296 & 296 & 296 \\
\hline Sampada x Jaya/3 & 18.3 & 24.2 & 21.3 & 0.6 & 0.7 & 0.6 & 7.9 & 8.9 & 8.4 & 311 & 288 & 299 \\
\hline $\begin{array}{l}\text { Varadhan x MTU } \\
1010 / 2\end{array}$ & 21.8 & 23.9 & 22.9 & 0.7 & 0.6 & 0.7 & 8.0 & 9.1 & 8.5 & 303 & 291 & 297 \\
\hline Rasi x Jaya/2 & 18.4 & 24.1 & 21.2 & 0.7 & 0.7 & 0.7 & 8.2 & 9.4 & 8.8 & 319 & 288 & 304 \\
\hline Varadhan & 20.1 & 19.1 & 19.6 & 0.7 & 0.7 & 0.7 & 8.8 & 10.1 & 9.5 & 315 & 312 & 313 \\
\hline BPT-5204 & 16.4 & 24.2 & 20.3 & 0.5 & 0.6 & 0.6 & 7.3 & 8.8 & 8.1 & 303 & 288 & 296 \\
\hline Sampada & 22.0 & 24.6 & 23.3 & 0.5 & 0.8 & 0.7 & 8.1 & 9.6 & 8.9 & 288 & 304 & 296 \\
\hline Jaya & 17.9 & 23.6 & 20.8 & 0.5 & 0.7 & 0.6 & 8.2 & 9.9 & 9.1 & 302 & 301 & 301 \\
\hline MTU-1010 & 20.4 & 23.1 & 21.7 & 0.6 & 0.6 & 0.6 & 8.2 & 9.0 & 8.6 & 296 & 295 & 295 \\
\hline Rasi & 19.5 & 20.9 & 20.3 & 0.5 & 0.6 & 0.5 & 7.7 & 9.2 & 8.4 & 292 & 297 & 295 \\
\hline Mean & 19.6 & 23.3 & 21.4 & 0.6 & 0.7 & 0.7 & 8.2 & 9.5 & 8.8 & 302 & 298 & 300 \\
\hline Treatments (T) & \multicolumn{3}{|c|}{0.4} & \multicolumn{3}{|c|}{0.1} & \multicolumn{3}{|c|}{0.2} & \multicolumn{3}{|c|}{4} \\
\hline Genotypes (G) & \multicolumn{3}{|c|}{1.04} & \multicolumn{3}{|c|}{0.1} & \multicolumn{3}{|c|}{0.6} & \multicolumn{3}{|c|}{10} \\
\hline TxG & \multicolumn{3}{|c|}{1.5} & \multicolumn{3}{|c|}{0.2} & & \multicolumn{3}{|c|}{15} \\
\hline
\end{tabular}


Table.4 The influence of nitrogen on partial factor productivity of nitrogen in different rice genotypes

\begin{tabular}{|l|c|c|c|}
\hline \multirow{2}{*}{\multicolumn{1}{c|}{ Genotypes }} & \multicolumn{2}{c|}{ Nitrogen Use Efficiency } & \multirow{2}{*}{ Mean } \\
\cline { 2 - 3 } & T1 & T2 & \\
\hline Varadhan x BPT 5204/6 & 15.88 & 6.30 & 11.09 \\
\hline Varadhan x BPT 5204/10 & 10.40 & 6.70 & 8.55 \\
\hline Sampada x Jaya/2 & 13.26 & 8.38 & 10.82 \\
\hline Sampada x Jaya/3 & 9.52 & 5.32 & 7.42 \\
\hline Varadhan x MTU 1010/2 & 14.44 & 7.59 & 11.02 \\
\hline Rasi x Jaya/2 & 15.78 & 8.15 & 11.97 \\
\hline Varadhan & 15.94 & 8.51 & 12.23 \\
\hline BPT-5204 & 11.84 & 6.15 & 9.00 \\
\hline Sampada & 12.88 & 7.91 & 10.40 \\
\hline Jaya & 13.86 & 8.70 & 11.28 \\
\hline MTU-1010 & 16.38 & 4.06 & 10.22 \\
\hline Rasi & 15.22 & 7.49 & 11.36 \\
\hline Mean & 13.78 & 7.11 & 10.44 \\
\hline Treatment (T) & & 0.14 & \\
\hline Genotypes (G) & & 0.10 & \\
\hline T x G & & 0.17 & \\
\hline
\end{tabular}

Table.5 The influence of nitrogen on root, stem and leaf nitrogen in different rice genotypes

\begin{tabular}{|l|l|l|l|l|l|l|l|l|l|}
\hline \multicolumn{1}{|c|}{ Genotypes } & \multicolumn{3}{|c|}{ Root nitrogen (\%) } & \multicolumn{3}{c|}{ Stem N(\%) } & \multicolumn{3}{c|}{ Leaf N(\%) } \\
\cline { 2 - 11 } & T1 & T2 & Mean & T1 & T2 & Mean & T1 & T2 & Mean \\
\hline $\begin{array}{l}\text { Varadhan x BPT } \\
\text { 5204/6 }\end{array}$ & 0.72 & 0.80 & 0.76 & 0.43 & 0.50 & 0.46 & 1.28 & 2.12 & 1.70 \\
\hline $\begin{array}{l}\text { Varadhan x BPT } \\
\text { 5204/10 }\end{array}$ & 0.70 & 0.71 & 0.71 & 0.64 & 0.65 & 0.65 & 1.50 & 1.84 & 1.67 \\
\hline Sampada x Jaya/2 & 0.71 & 0.79 & 0.75 & 0.58 & 0.79 & 0.69 & 1.85 & 1.98 & 1.91 \\
\hline Sampada x Jaya/3 & 0.57 & 0.82 & 0.70 & 0.66 & 0.73 & 0.70 & 1.75 & 2.00 & 1.88 \\
\hline $\begin{array}{l}\text { Varadhan x MTU } \\
\text { 1010/2 }\end{array}$ & 0.72 & 0.92 & 0.82 & 0.50 & 0.51 & 0.51 & 1.66 & 1.98 & 1.82 \\
\hline Rasi x Jaya/2 & 0.65 & 0.88 & 0.77 & 0.50 & 0.52 & 0.51 & 1.94 & 2.19 & 2.07 \\
\hline Varadhan & 0.86 & 0.75 & 0.81 & 0.40 & 0.48 & 0.44 & 1.68 & 2.35 & 2.02 \\
\hline BPT-5204 & 0.72 & 0.79 & 0.76 & 0.57 & 0.77 & 0.67 & 1.91 & 1.93 & 1.92 \\
\hline Sampada & 0.68 & 0.81 & 0.75 & 0.62 & 0.68 & 0.65 & 1.51 & 1.66 & 1.59 \\
\hline Jaya & 0.73 & 0.78 & 0.76 & 0.42 & 0.81 & 0.62 & 1.57 & 1.91 & 1.74 \\
\hline MTU-1010 & 0.65 & 0.80 & 0.73 & 0.36 & 0.60 & 0.48 & 1.47 & 1.65 & 1.56 \\
\hline Rasi & 0.99 & 0.95 & 0.97 & 0.64 & 1.06 & 0.85 & 1.45 & 1.53 & 1.49 \\
\hline Mean & 0.73 & 0.82 & 0.77 & 0.50 & 0.70 & 0.60 & 1.60 & 1.90 & 1.80 \\
\hline Treatments (T) & & 0.06 & & & NS & & & NS & \\
\hline Genotypes (G) & & 0.05 & & & 0.19 & & & NS & \\
\hline T x G & & 0.06 & & & NS & & & NS \\
\hline
\end{tabular}


Table.6 The influence of nitrogen on photosynthetic nitrogen use efficiency and Harvest Index in different rice genotypes

\begin{tabular}{|c|c|c|c|c|c|c|}
\hline \multirow[t]{2}{*}{ Genotypes (G) } & \multicolumn{3}{|c|}{$\begin{array}{c}\text { Photosynthetic rate/ } \\
\text { Leaf } \mathbf{N}\end{array}$} & \multicolumn{3}{|c|}{ Harvest index (\%) } \\
\hline & T1 & T2 & Mean & T1 & $\mathbf{T} 2$ & Mean \\
\hline $\begin{array}{l}\text { Varadhan x BPT } \\
5204 / 6\end{array}$ & 23.15 & 11.84 & 17.50 & 51 & 46 & 48 \\
\hline $\begin{array}{l}\text { Varadhan x BPT } \\
5204 / 10\end{array}$ & 12.64 & 12.69 & 12.67 & 45 & 48 & 47 \\
\hline Sampada x Jaya/2 & 11.80 & 12.29 & 12.05 & 49 & 48 & 48 \\
\hline Sampada x Jaya/3 & 10.83 & 12.17 & 11.50 & 46 & 43 & 44 \\
\hline $\begin{array}{l}\text { Varadhan x MTU } \\
1010 / 2\end{array}$ & 13.26 & 12.31 & 12.79 & 49 & 49 & 49 \\
\hline Rasi x Jaya/2 & 9.48 & 11.02 & 10.25 & 49 & 50 & 50 \\
\hline Varadhan & 12.13 & 8.10 & 10.12 & 48 & 53 & 50 \\
\hline BPT-5204 & 8.55 & 12.90 & 10.73 & 47 & 43 & 45 \\
\hline Sampada & 14.77 & 14.83 & 14.80 & 48 & 48 & 48 \\
\hline Jaya & 11.66 & 12.44 & 12.05 & 45 & 53 & 49 \\
\hline MTU-1010 & 13.86 & 14.00 & 13.93 & 46 & 29 & 38 \\
\hline Rasi & 13.50 & 15.37 & 14.44 & 45 & 50 & 47 \\
\hline Mean & 12.97 & 12.50 & 12.73 & 47.3 & 46.5 & 46.9 \\
\hline Treatments (T) & \multicolumn{3}{|c|}{0.80} & \multicolumn{3}{|c|}{ NS } \\
\hline Genotypes (G) & \multicolumn{3}{|c|}{0.17} & \multicolumn{3}{|c|}{ NS } \\
\hline T xG & \multicolumn{3}{|c|}{0.29} & \multicolumn{3}{|c|}{ NS } \\
\hline
\end{tabular}

In conclusion, present study found that there are wide variations in physiological parameters, grain yield, $\mathrm{N}$ content in different plant parts as well as nitrogen use efficiency, grain yield efficiency and harvest indices among genotypes under two nitrogen regimes. With the exception to Vardhan x BPT 5204/6, MTU-1010 and Rasi all the entries included in this field experiment showed reduction in grain yield under $50 \%$ RDN. Vardhan and Rasi x Jaya/2 recorded highest average grain yield with high nitrogen use efficiency.

Hence, they were identified as nitrogen efficient genotypes because they consistently produced high grain yield.

\section{Acknowledgement}

I acknowledge the help received from Indian Institute of Rice Research (IIRR), Rajendranagar, Hyderabad during the research work.

\section{References}

Devika, S., Ravichandran, V., Boominathan, P. (2018). Physiological analyses of nitrogen use efficiency and yield traits of rice genotypes. Indian Journal of Plant Physiology, 23, 100-110.

Gomez, K.A and Gomez, A.A. (1984). Statistical Procedures for Agricultural Research, second ed. John Wiley \& 
Sons, New York, USA, 680 pp.

Good, A. G., Shrawat, A. K., Muench, D. G. (2004). Can less yield more? Is reducing nutrient input into the environment compatible with maintaining crop production? Trends in Plant Science, 9, 597-605.

Li, Y., Yang, X., Ren, B., Shen, Q., Guo, S. (2012). Why Nitrogen Use Efficiency Decreases Under High Nitrogen Supply in Rice (Oryza sativa L.) Seedlings. Journal of Plant Growth and Regulation, 31, 47-52.

Mae, T. (1997). Physiological nitrogen efficiency in rice: nitrogen utilization, photosynthesis and yield potential. Plant and Soil, 196, 201-210.

Makino, A., Shimada, T., Takumi, S., Kaneko, K., Matsuoka, M., Shimamoto, K., Nakano, H., Miyao Tokutomi, M., Mae, T., Yamamoto, N. (1997). Does decrease in ribulose1, 5-bisphosphate carboxylase by antisense $\mathrm{RbcS}$ lead to a higher $\mathrm{N}$-use efficiency of photosynthesis under conditions of saturating $\mathrm{CO} 2$ and light in rice plants? Plant Physiology, 114, 483-491.

Pramanik, K., and Bera, A.K. (2013). Effect of seedling age and nitrogen fertilizer on growth, chlorophyll content, yield and economics of hybrid rice (Oryza sativa L.). International Journal of Agronomy and Plant Production, 4, 3489-3499.

Rajput, M.K.K., Ansari, A.H., Mehdi, S., Hussain, A.M. (1988). Effect of $\mathrm{N}$ and $\mathrm{P}$ fertilizers alone and in combination with OM on the growth and yield of Toria. Sarhad Journal of Agriculture Research, 4, 3-6.

Sage, R.F and Pearcy, R.W. (1987). The nitrogen use efficiency of $\mathrm{C} 3$ and $\mathrm{C} 4$ plants. Plant Physiology, 84, 959-963.

Sun, Y., Maa, J., Sun, Y., Xu, H., Yang, Z., Liu, S., Jia, X., Zheng, H. (2012). The effects of different water and nitrogen managements on yield and nitrogen use efficiency in hybrid rice of China. Field Crops Research, 127, 85-98.

Yoshida, S and Coronel, V. (1976). Nitrogen nutrition, leaf resistance, and leaf photosynthetic rate of the rice plant. Soil Science \& Plant Nutrition, 22, 207-211.

Zhang, Y., Wang, H., Liu, S., Lei, Q., Liu, J., He, J., Zhai, L., Ren, T., Liu, H. (2015). Identifying critical nitrogen application rate for maize yield and nitrate leaching in a Haplic Luvisol soil using the DNDC model. Sci. Total Environ. 514, 388-398.

\section{How to cite this article:}

Aparna, V., S. Narender Reddy and Subrahmanyam, D. 2019. Study on Genotypic Differences in Photosynthetic Nitrogen Use Efficiency, Nitrogen Use Efficiency, Yield and Yield Related Traits in Different Rice Genotypes under Different Nitrogen Levels. Int.J.Curr.Microbiol.App.Sci. 8(04): 2484-2493. doi: https://doi.org/10.20546/ijcmas.2019.804.289 